\title{
10. SITE SURVEY FOR SITE 410, AN EXAMPLE OF THE USE OF LONG-RANGE SIDE-SCAN SONAR (GLORIA)
}

\author{
R. C. Searle and A. S. Laughton, Institute of Oceanographic Sciences, Wormley, GU8 5UB, UK \\ and \\ B. D. Loncarevic, Bedford Institute of Oceanography, Dartmouth, Nova Scotia, Canada
}

\begin{abstract}
We describe the use of the long-range, side-scan sonar GLORIA, in a site survey for Site 410 . The system provides a means for fast, highresolution surveying of a wide area, and facilitates great precision in site selection.
\end{abstract}

\section{INTRODUCTION}

It was proposed that a site be drilled on or near magnetic anomaly 5 , at about $45^{\circ} \mathrm{N}$ in the region of detailed surveys organized by Bedford Institute of Oceanography in the 1960s. These surveys had provided very detailed bathymetric, gravity, and magnetic charts of the area concerned, together with a fairly dense collection of samples from conventional coring and dredging operations (Aumento et al., 1971). However, sediment distribution and thickness in the area of interest were less well known. We therefore planned a site survey to obtain additional information on sediment distribution, and to observe the area with the long-range, side-scan sonar GLORIA, which provides visual information on sea-floor morphology over a wide area, with very high horizontal resolution (Rusby and Somers, 1977).

\section{SITE SURVEY}

The survey was carried out during cruise 73 of R.R.S. Discovery, on 13 and 14 July 1975 . A grid of northeastsouthwest and northwest-southeast track lines, spaced 8 to 18 $\mathrm{km}$ apart, was used. Sediment profiling was carried out using a conventional 40 -in. ${ }^{3}$ airgun with a single-channel hydrophone receiver. GLORIA was used with the sonar beam directed either northwest with a 26-km maximum range, or northeast with a $13-\mathrm{km}$ range. The GLORIA sonographs were anamorphosed photographically to take account of variations in ship's speed, and mosaicked to provide a continuous representation of features in the survey area (Figure 1) and to minimize distortions resulting from the non-linear display of horizontal distance at short range. The horizontal resolution of the mosaic is better than 50 meters. Conventional echo-sounding and magnetic data were also obtained.

\section{INTERPRETATION}

GLORIA sonographs have now been used to study several areas on the northern Mid-Atlantic Ridge crest (Laughton and Rusby, 1975; Whitmarsh and Laughton, 1976; Searle and Laughton, 1977; Laughton et al., in press). These studies indicate that outcrops of igneous rock generally give rise to high-intensity sonar echoes (white in Figure 1), whereas sediments, which provide a nearly specular reflecting surface, produce little back-scattering of sound energy and appear dark gray. Narrow, linear echoes indicate steep scarps, probably fault-scarps. Areas of acoustic shadow show as black.

By utilizing this information and combining it with the airgun profiler data, we were able to produce a fault and basement outcrop map (Figure 2). With this as a basis, we then drew an isopach map (Figure 3), a preliminary version of which was made available to the Leg 49 shipboard party. Study of these maps, together with the sonograph mosaic and the Bedford Institute bathymetry (Figure 4), allows detailed visualization of the three-dimensional structure of the area.

Most of the topographic ridges in the area are seen to be sites of basement outcrop, and are bounded by fault-scarps dipping toward the Mid-Atlantic Ridge axis and striking north to northeast. In three places these ridges and faults terminate along east-west lines: at $45^{\circ} 41^{\prime} \mathrm{N}, 29^{\circ} 14^{\prime}$ to $29^{\circ} 27^{\prime} \mathrm{W}$; at $45^{\circ} 30^{\prime} \mathrm{N}, 29^{\circ} 11^{\prime}$ to $29^{\circ} 18^{\prime} \mathrm{W}$; and at $45^{\circ} 28^{\prime} \mathrm{N}$, $28^{\circ} 58^{\prime}$ to $29^{\circ} 09^{\prime} \mathrm{W}$. At the last of these lineations, the northsouth faults have a sharp dextral curvature. These east-west lineations probably represent small, short-lived fracture zones. None is continuous throughout the survey area, for in each case a well-defined $010^{\circ}$-trending scarp crosses the prolongation of the east-west lineation without offset. There is a general dextral offset of the spreading axis in this area, however, as indicated by the shape of magnetic anomaly 5 (Figure 3). This may have been accomplished by the small fracture zone offsets, and perhaps also by en-echelon or oblique spreading.

\section{SITE SELECTION}

In suggesting possible drill sites, we considered the following criteria:

a) sediment thickness should exceed 100 meters;

b) the site should lie over a block of uniform magnetic polarity, preferably anomaly 5 ;

c) the site should be clear of fracture zones;

d) the site should avoid areas of recent tectonic activity and be well away from obvious basement faults.

Two basins between $29^{\circ} 20^{\prime}$ and $29^{\circ} 30^{\prime} \mathrm{W}$ appeared to be suitable; they have undeformed sediment surfaces, ample sediment, and overlie anomaly 5. Using the airgun and sonar data to aboid faults, we suggested the following three drill sites (Figure 2): 


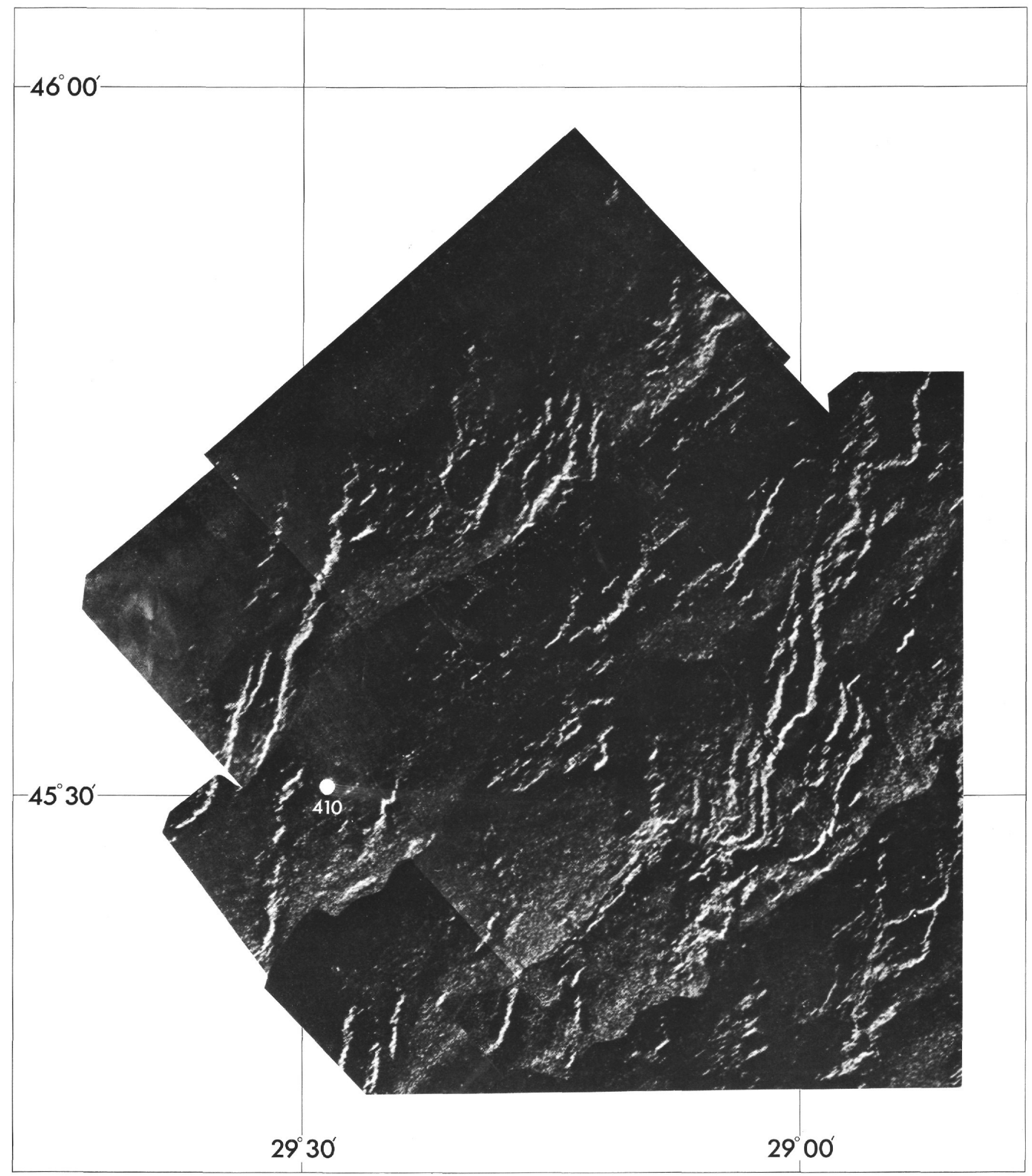

Figure 1. Mosaic of northwest-looking GLORIA sonographs.

\begin{tabular}{cccc}
\hline Site & $\begin{array}{c}\text { Latitude } \\
(\mathrm{N})\end{array}$ & $\begin{array}{c}\text { Longitude } \\
\text { (W) }\end{array}$ & $\begin{array}{c}\text { Sediment Thickness } \\
\text { (seconds, two-way) }\end{array}$ \\
\hline A & $45^{\circ} 23.5^{\prime}$ & $29^{\circ} 27.0^{\prime}$ & 300 \\
B & $45^{\circ} 26.5^{\prime}$ & $29^{\circ} 22.0^{\prime}$ & 400 \\
C & $45^{\circ} 31.4^{\prime}$ & $29^{\circ} 27.8^{\prime}$ & 350 \\
\hline
\end{tabular}

Site A was thought to be best; B was rather close to the edge of anomaly 5 , and $\mathrm{C}$ lay over the region of offset of anomaly 5.

In the event, Site 410 was drilled at $45^{\circ} 30.51^{\prime} \mathrm{N}$, $29^{\circ} 28.56^{\prime} \mathrm{W}$, about $2 \mathrm{~km}$ southwest of Site C, in 340 meters of sediment. A major fault-scarp lies about $3 \mathrm{~km}$ to the west 


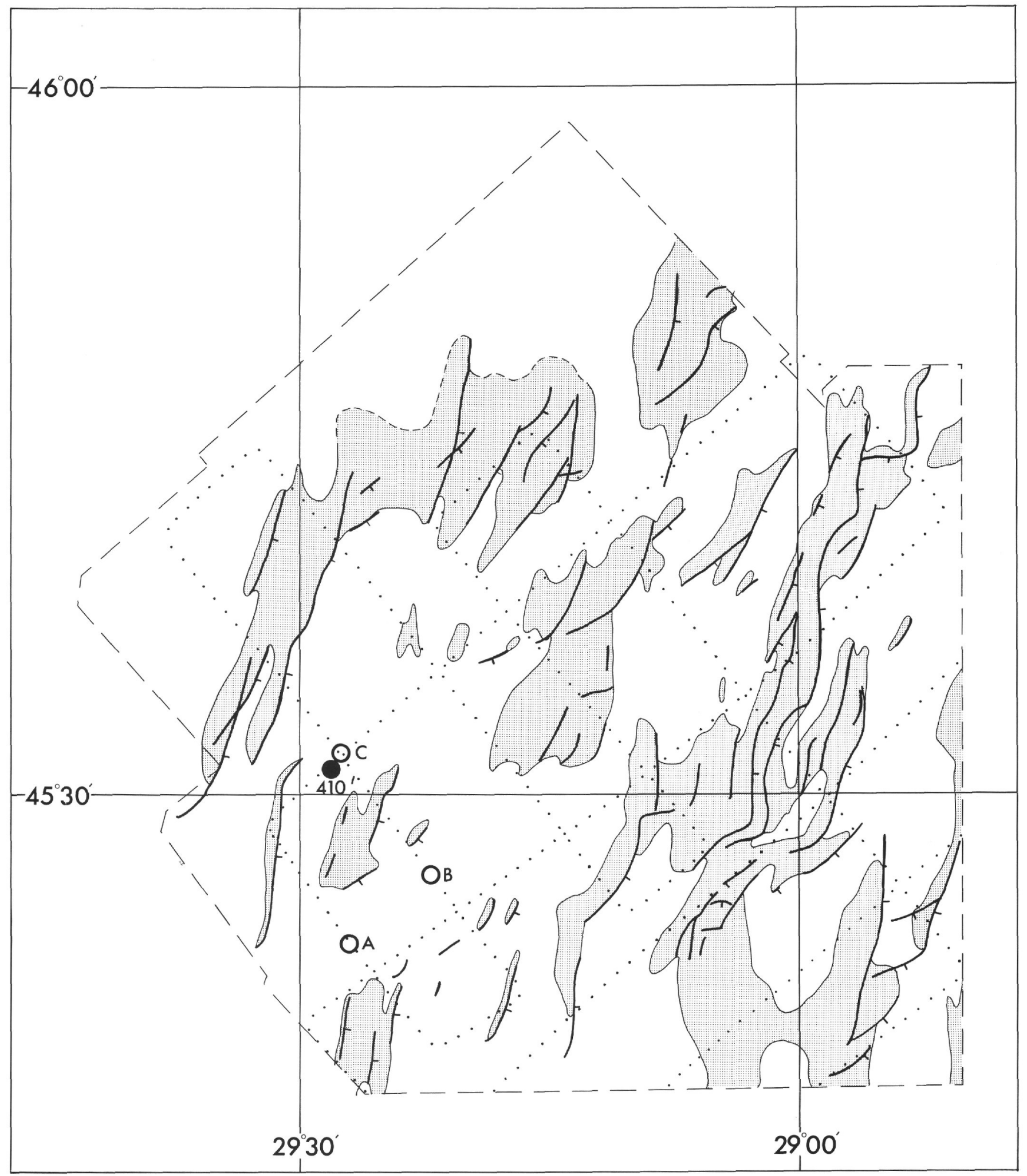

Figure 2. Basement outcrops (shaded) and fault traces. 
R. C. SEARLE. A. S. LAUGHTON, B. D. LONCAREVIC

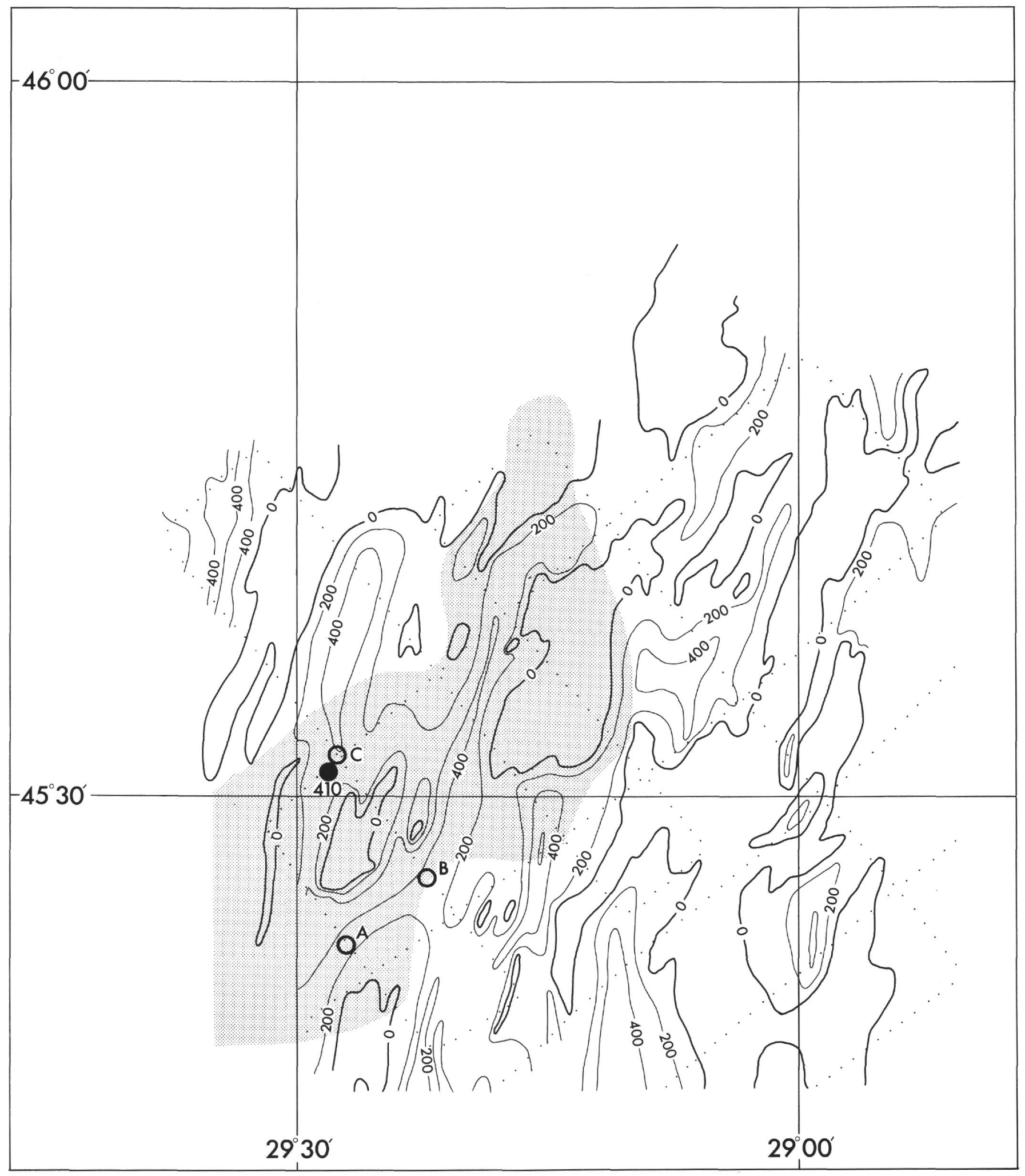

Figure 3. Isopach map, contour interval 200 milliseconds two-way travel time. Shading indicates magnetic anomaly 5. 


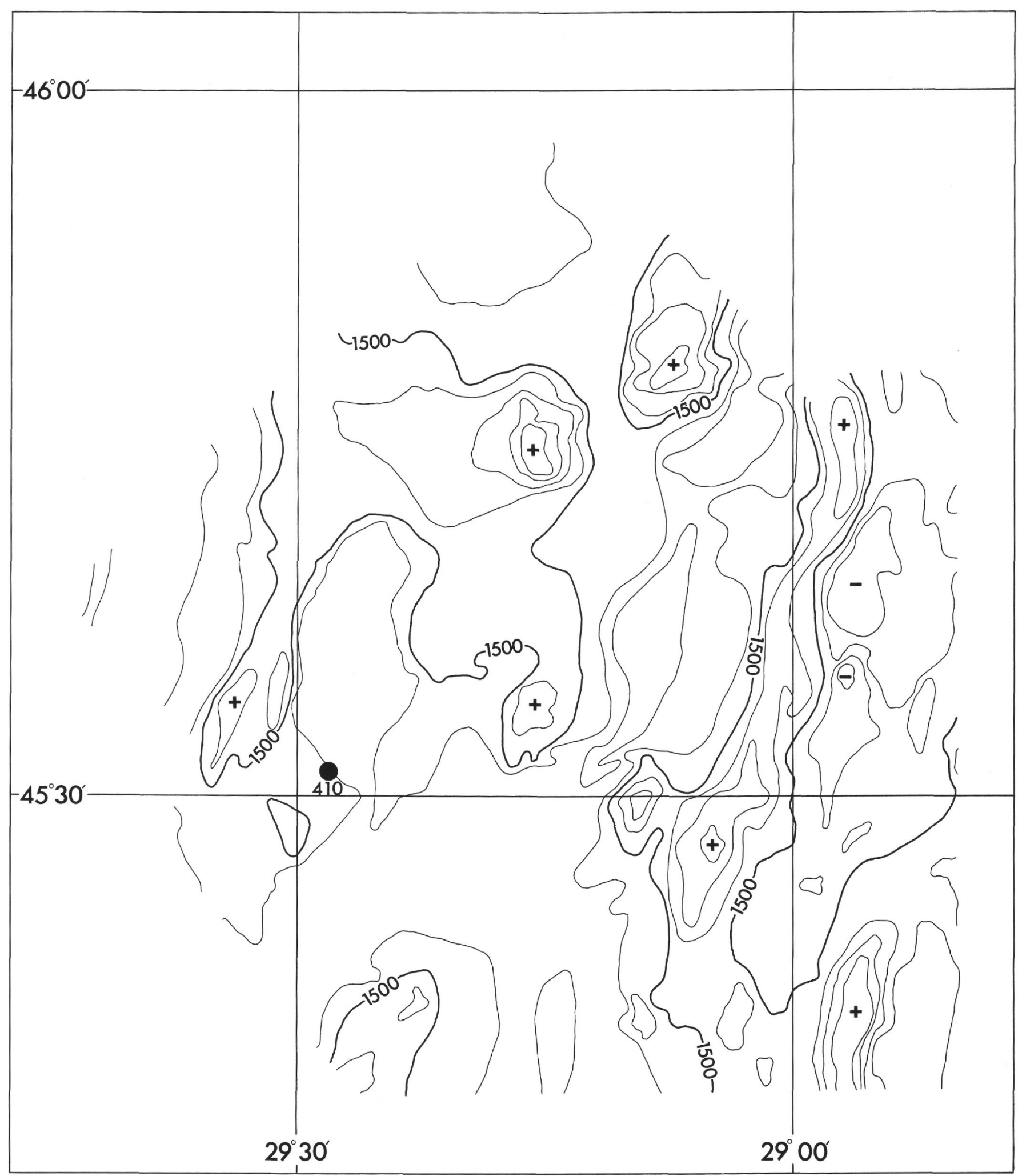

Figure 4. Bathymetry in uncorrected fathoms from Aumento et al., 1971. 
of the site, and a small ridge outcrops about $2 \mathrm{~km}$ to its east (Figures 1 and 2). The site is near the northern terminations of both features.

\section{CONCLUSION}

We believe this example demonstrates the power of the GLORIA system for rapid, high-resolution surveying with continuous areal coverage. This makes it an ideal technique for preliminary site surveys, where it is required to locate a site precisely in relation to such geological features as outcrops or fault-scarps. It should be equally useful for choosing sites for submersible or deep-towed surveys, dredging and coring, as well as drilling.

\section{ACKNOWLEDGMENTS}

We thank the master, officers, crew, and shipboard scientists of R.R.S. Discovery Cruise 73.

\section{REFERENCES}

Aumento, F., Loncarevic, B. D., and Ross, D. I., 1971. Hudson Geotraverse: geology of the Mid-Atlantic Ridge at $45^{\circ} \mathrm{N}$, Phil. Trans. Roy. Soc. London, Ser. A., v. 268, p. 623-650.

Laughton, A. S. and Rusby, J. S. M., 1975. Long-range sonar and photographic studies of the median valley in the FAMOUS area of the Mid-Atlantic Ridge near $37^{\circ} \mathrm{N}$, Deep-Sea Research, v. 22 , p. 279-298.

Laughton, A. S., Searle, R. C., and Roberts, D. G., in press. The Reykjanes Ridge crest and the transition between its rifted an non-rifted regions. Tectonophysics.

Rusby, J. S. M. and Somers, M. L., 1977. The development of the "GLORIA" sonar system from 1970-75. "Voyage of Discovery,' Deep-Sea Research, v. 24, Supp., p. 611-625.

Searle, R. C. and Laughton, A. S., 1977. Sonar studies of the Mid-Atlantic Ridge Crest and Kurchatov Fracture Zone, $J$. Geophys. Res., v. 82, p. 5313-5328.

Whitmarsh, R. B. and Laughton, A. S., 1976. A long-range sonar study of the Mid-Atlantic Ridge crest near $37^{\circ} \mathrm{N}$ (FAMOUS area) and its tectonic implications, Deep-Sea Research, v. 23, p. $1005-1023$. 